\title{
University of Sydney
}

\section{A. Andreas Wansbrough}

\section{Body as spirit: Lars Von Trier's Nymphomaniac and Hegel's Phenomenology}

\begin{abstract}
:
Lars von Trier's film, Nymphomaniac, explores a female protagonist's, Joe's, bodily suffering and pleasure from the age of two to fifty. We are first introduced to Joe by her beaten body. Joe is found by Seligman who wants to hear her story. This story, which concerns her sexual journeys, has a strong metaphysical component and involves a type of spiritual self-laceration through the body. While one may expect a film about sex to concern the orgasmic, the film instead shows a failed attempt at union. Using Hegel's account of the Geist's (Spirit/Mind's) enervation in Phänomenologie des Geistes/The Phenomenology of Spirit, I will contend that Lars von Trier's film is about starvation as much as it is about excess, both bodily and psychical. Hegel describes Geist as defeated in its triumph and always looking for a fulfillment that cannot occur. While Hegel does provide a teleological narrative of the human spirit's movement, spiritual perfection Geist's union with its surroundings - is always in some sense beyond the Geist. Likewise, Nymphomaniac's narrative moves through time, but is empty of any sense of place. This article argues that Joe is forever a purgatorial identity, a physical manifestation of tortured Hegelian Geist.
\end{abstract}

\section{Biographical note:}

A. Andreas Wansbrough is a PhD Candidate at Sydney College of the Arts, University of Sydney. He is currently completing a $\mathrm{PhD}$ that aims to understand questions in the philosophy of the tragic by examining themes of nature and fate in Lars von Trier's work. $\mathrm{He}$ is an editorial assistant at the Australasian Journal of Popular Culture.

Keywords:

Narrative - Film - Nymphomaniac - The Phenomenology of Spirit - von Trier, Lars Hegel 

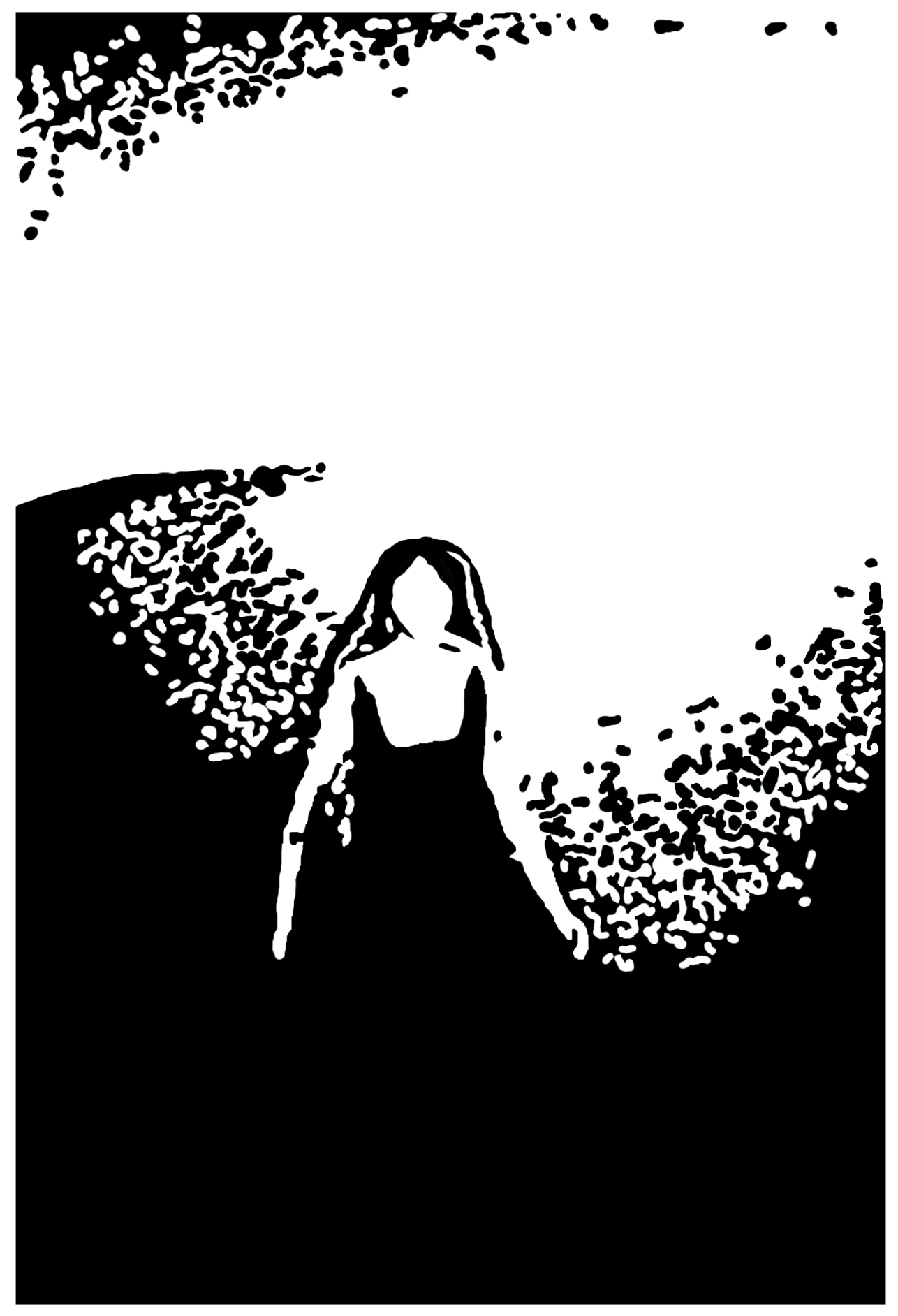

Fig. 1. Ulrike Sturm, Dialectic, linocut, 2016 


\section{Introduction}

Feminism has always supposed that the personal is political. The personal starts with the person, which in turn begins with the body. The female human body, as Rachel Franks observes in the previous article, is a contested site between self-expression and commodification. The respect for the body, for its rights and integrity, is fundamental and yet for men to view women in terms of the body is reductive - male-chauvinists and misogynists very often view women as nothing else. Lars von Trier's film, Nymphomaniac (2013), bespeaks a spiritual, indeed a theological dimension, to the bodily experience of a fictional woman through the writing of a screenplay in which the narrative of this woman unfolds. This screenplay frames Joe's bodily experience through metaphysics, and thereby acknowledges both the significance of the body and a sense that bodily experience and pleasure fail to contain female subjectivity - there is something beyond mere physiology in Joe's experience of her body and the bodies of others. Von Trier's films, including Nymphomaniac, often arouse controversy around his depictions of women. A number of feminist academics, critics and activists criticise his films, on the grounds that his depiction of gendered violence reveals von Trier's own sadism toward his women protagonists or because they cater, and thereby reinforce, the sado-masochistic thrill of watching women undergo extreme forms of suffering (Faber 2003, Brooks 2009).

Yet, other critics find something appealing about von Trier's films, interpreting them as depicting subversive, strong women protagonists (Keefer and Linafelt 1999, Brooks 2009). Furthering this ambiguity in von Trier's films is the sense that the women protagonists are often triumphant and defeated at the same time. These two interpretations go to the core of debates and paradoxes within feminism where sex can be both celebrated and condemned. Anti-pornography feminists, for example, accuse sex-positive feminists of ignoring or even participating in the very sexual objectification that instrumentalises women, and pro-sex feminists argue that anti-porn feminists reinforce the conservative moralism that places shackles on women's subjective pleasure, imprisoning their libido. Indeed, sexual experience can be both damaging and affirmative, and sometimes occupies the position of simultaneously being both, which may explain the contestations that occur within feminism. Nymphomaniac reveals this tension and exploits it, depicting sex acts that reveal the pleasure of surpassing limits and the limits that are reinscribed into transgressive pleasure. The paradoxes within such sexual experience bespeak the need of a paradoxical framing. Using Georg Wilhelm Friedrich Hegel's account of Geist's progress in Phänomenologie des Geistes/The Phenomenology of Spirit (1807), I will draw parallels between Joe's sexual conquests and failures with Geist's experience of elevation and enervation, fullness and starvation, revealing the dialectical implications of Joe's sexual journey. These implications relate to concerns of gender, sexuality and emancipation, but also existential concerns about the human condition: concerns that have driven much creative practice, including writing. Indeed, such concerns relate to autobiography - how the self is written and exposed through its enunciation, and how such forms of self-expression are open to a dialectical contestation.

Although I would consider myself to be a feminist, I acknowledge from the outset that 
there are gulfs in lived experience between my privileged position as a white male and the various forms of oppression and repression that many women face. I hope to offer some form of redemption for both Nymphomaniac and the Phenomenology. This article should be read as less of an apologetics and more as an apology. Rather than attempting to make a feminist case for either Nymphomaniac or the Phenomenology, I wish to offer a framing that encompasses some feminist concerns, and create a dialogue between the Phenomenology and Nymphomaniac that enriches their depiction of human experience by drawing on an analysis of capitalism and gender. Ultimately, both Nymphomaniac and the Phenomenology go beyond gender and culture to the existential dimension of the human condition that is so often cloaked and disguised by custom and the assumptions of contemporary Western societies. As Michel Foucault suggests in his work The History of Sexuality (1978), we must be sceptical of the smug complacent sense of progress and realise that there are still very real repressions and oppressions that continue amidst emancipatory movements (Part I, 'We Other Victorians').

\section{Joe and Hegel}

Lars von Trier's Nymphomaniac explores Joe's bodily suffering and pleasure from the age of two to fifty. We are first introduced to her by her beaten body. Joe is found by Seligman who wants to hear her story. Joe tells it, relishing the details in her attempt to shock him. Her story, which concerns her sexual explorations, has a strong metaphysical component, and involves a type of spiritual self-laceration through the body. While one may expect a film about sex to concern the orgasmic, the film instead shows a failed attempt at union. The work moves not only through climaxes but interrupted climaxes, the anticlimactic. Von Trier himself has characterised the work as a digressive mode of cinema, borrowing the narrative structure from literature - the two-volume film is broken up into chapters. Joe's sexual quest for fulfilment is metaphysical but expressed in a phenomenological way as with Hegel's account of Geist. In the Phenomenology, Hegel talks not only of the triumph of the human spirit but about its starvation that occurs after its excess, both bodily and psychical. Hegel describes Geist as defeated in its triumph and always looking for a fulfilment that cannot occur. While Hegel does provide a teleological narrative of the human spirit's movement, spiritual perfection - Geist's union with its surroundings - is always in some sense beyond Geist. Likewise, Nymphomaniac's narrative moves through time, but is empty of any sense of place or closure. This article argues that Joe is forever a purgatorial identity, resembling, in some respects, a physical manifestation of tortured Hegelian Geist, and assuming existential, theological, gendered and political dimensions. Geist exists as both Spirit (as in spiritedness) and Mind, and is therefore a merging of activity and reflection that allows us to understand the peculiar way that her actions are at once impulsive and reflective. Moreover, this approach echoes the film's structure which follows both Joe's activity and her conversations with Seligman. Geist is spiritual and analytical and pervades all human activities allowing us to conceive of Joe's actions through different registers and various vantages, whether political, metaphysical, theological, moral, cultural or philosophical.

Due to the length of Nymphomaniac, the film was released in two volumes. Even then, 
there was a redacted version of the film and a Director's cut (2014: vol I, vol II). Most of what follows in this article applies to both versions, referencing the earlier release unless otherwise stated. Volume I opens with a black screen and the sounds of an air vent and dripping water. This creates a sense of foreboding. An opportunity, for a few seconds at least, for viewers to construct their own opening scene; to write their own entry point into the main narrative. We see Joe (played at this point by Charlotte Gainsbourg, but in many of the flashbacks a younger Joe is played by Stacy Martin), lying, beaten in the snow. The film then cuts to Seligman (Stellan Skarsgård), a humble looking man, who journeys out into the cold to buy groceries. On the way back to his apartment, he sees Joe in her battered state. He offers to call an ambulance or the police but Joe refuses, threatening to leave. Seligman realises how badly injured she is and invites her back into his house for tea and rest. Joe and Seligman converse about notions of evil and sexual addiction. Seligman disbelieves Joe that she is a 'bad human being'. He also reveals that he has no interest in sex and yet is not religious. Joe, on the other hand, seems to have internalised religious notions about sin, and claims not only to be a bad human being but also a nymphomaniac. To prove her own monstrosity and perversity, Joe tells her story of sexual addiction. Her words relay her experiences of 'nymphomania' which are both a confirmation and a denial of her sexual addiction. According to Joe's account, her thirsts, desires and experiences of abjection constitute the narrative of her life. The narrative becomes almost like a novel, progressing and exposing her desires.

In volume I, she informs Seligman about when she first engaged in sexual activity with her friend B at the age of two - she and B would overflow the sink with water and slide against the wet ground. We also learn about her first sexual experience with a young man named Jerôme (Shia LaBeouf) who has rather unpleasant sex with her. Later on, she encounters Jerôme again working in a printing company and develops feelings for him, while refusing his sexual advances. However, Jerôme runs away with the secretary who works for the firm before Joe has a chance to confess her feelings. Later, after Joe takes different lovers, Jerôme returns. Joe, however, discovers that she can no longer enjoy or desire sex, which destabilises her whole identity. She is unable to find Jerôme sexually stimulating, and is therefore unable to physically express her love, to find fulfilment through sex.

In volume II, despite their sexual problems, Joe and Jerôme have a son. Joe's sexuality returns with a vengeance and Jerôme is unable to satisfy her. He allows her to take other lovers. Eventually, Joe goes further and further with her sexual desires. She finds a person known as K (Jamie Bell) who, while denying her penetrative sex, beats her sexually and abuses her. (This is not quite true as $\mathrm{K}$ does, at one point, penetrate Joe digitally. However, the penetration is a reward and in a way, a compromise for $\mathrm{K}$ who still will not consummate his sexual desire in a more conventional manner.) Her visits to $\mathrm{K}$ come at the expense of time with her son, and Jerome takes their son from her and gives him up for adoption. Her sexual addiction leads her to go into debt collecting. She ultimately enlists the help of a teenage girl, P (Mia Goth), and they form a sexual and romantic relationship. Unfortunately, Joe's brief period of hope is interrupted. Joe discovers that the next person she must collect debt from is Jerôme. She sends P in her 
place. However, P and Jerôme form a relationship. Joe attempts to take her revenge and pulls a gun on Jerôme. She tries to shoot him but it will not fire. Jerôme then beats Joe and $\mathrm{P}$ pisses on her. They leave her in the state that Seligman finds her in.

In this abject state, Joe says, 'Fill all my holes', a statement that both has a bodily and metaphysical-existential and ontological connotation (2013: vol II). Jerôme and P have just had sex in the same manner that Jerôme first had sex with Joe when she ceased to be a virgin - penetrating her both vaginally and anally. Such an experience thereby has connotations with wishing to return to a site of origin, and an attempt for her void, her emptiness to be filled. There is a fundamental gap between Joe and her world. Joe experiences a type of freedom through sex and physicality. Joe feels cut-off from the world, as though her experiences and sensations place her above the realm of ordinary sexual experience. Yet, the sex is always in part anti-climactic and she is left with nothing. In another, earlier, scene Joe appropriates Seligman's account of a polyphony by Bach (the music: Ich ruf zu dir, Herr Jesu Christ, BWV 639, plays during the sequence) to describe her experiences of her lovers. However, the analogy of a sexual polyphony is frustrated, as Jerôme is unable to satisfy her sexual desires. Joe's every point of near completion ends in failed union, as the musical harmony is denied her. Music helps to represent Joe's experiences. Von Trier uses a modified version of Rammstein's music, Führe mich, early in the film. The lyrics have an existential and metaphysical dimension, 'lead me, hold me', 'two souls span a skin', 'you are built close to me' (Vesth and Von Trier 2013 ${ }^{1}$ ). The song has a rawness and violence and the voice has a sense of longing, and implies a link, a unity between Joe and her lovers that is never manifested. Indeed, the use of Mozart's Requiem Mass in D Minor (1791, posthumously completed in 1792) may also suggest this failed union as Mozart never completed the composition and it is a work of mourning. This sense of death and failure and incompletion bespeaks Joe's struggles.

There is something reminiscent in Joe's ongoing quest for completion of Hegel's account of Geist in the Phenomenology. Geist is constantly losing itself in its expression, and advances only by confronting its own destruction. As Katrin Pahl observes in her essay, 'The way of Despair', 'the Phenomenology presents ... despair as a spiritual and physical ruin' (2011). This ruin is part of the development of the subject, as Pahl further observes, 'the subject in despair loses its head, its every bone is broken, it self-digests, its heart breaks, its spirit is crushed but restless' (2011). Pahl is eager to confront the interpretation that Hegel's Phenomenology presents a narrative of constant progress. Rather, Hegel's Phenomenology is a narrative of 'the way of despair'. If we follow Pahl's reading, there is an inviting parallel between Joe's experience and the experience of Hegel's Geist. Joe's body is battered and bruised, she is wounded to her core, and broken, and she despairs of the world and herself. Yet she goes on.

\section{Reconciling Hegel's Geist with Joe's bodily quest}

Hegel's Phenomenology explores the development of the subject through the movement of Geist. It is important here to note that the function, purpose, meaning and 
relation of the Phenomenology to Hegel's overall philosophical project is hotly contested. Indeed, a number of commentators view it as a type of philosophical novel, a Bildungsroman, rather than a true philosophical exposition of his ideas (Redding 2010: Section 3.1; see also, Findlay 1977: v). Terry Pinkard provides an encapsulation of these various reactions to the Phenomenology, 'it has been held, variously, to be a "coming of age" novel (a Bildungsroman), a new version of the divine comedy, a tragedy, a tragi-comedy, a work in epistemology, a philosophy of history, a treatise in Christian theology, and an announcement of the death of God' (Pinkard 2013: 222). Almost all of these claims seem to encompass Nymphomaniac which is a type of sexual Bildungsroman that blurs the lines between theology, personal history, comedy and tragedy. Indeed, Nymphomaniac is at once a novel and a philosophical dialogue. The work engages the audience is a way that is more commonly associated with literary complexity than film. Joe's adventures are always misadventures and we, as an audience, have a complicated and ambivalent relationship to them. According to Rosalind Galt in her essay, 'The Suffering Spectator?: Perversion and Complicity in Antichrist and Nymphomaniac', Nymphomaniac is notably open to different interpretations and emotional experiences from the audience, including humour and horror. Galt claims that the audience, like Joe, know that they will experience 'a challenging mix of pleasure and pain; ... agreeing to suffer' (2015). This fusion of pleasure and pain, establishes a relationship between Joe and the audience. It also allows for a connection to be established with Hegel's Phenomenology, for Geist's searches summon a complicated blend of pain and pleasure. Pahl notes that the spiritual despair in the Phenomenology has an almost sexual quality, claiming that, 'the subject is segmented; truth is offered up in morsels. We linger on each part of the textual body' (2011). As Pahl notes, Hegel's Geist itself can be deemed sexy in the way it is described and built up, a way that fuses pleasure and pain, anticipation and a constant forestalling of climax. Indeed, the very climax of the Phenomenology suggests the possibility of an absolute understanding of self and world through the notion of absolute knowledge, but it never delivers.

Hegel's account of Geist is paradoxical and in such a way that can frame Joe's sexual experiences. Expanding on the sexual dimension that can be read into Hegel, one can reflect that Geist has a sexual quality that transcends gendered and sexual demarcations, being both feminine and masculine. Geist has a phallic sensibility, attempting to penetrate every domain of knowledge, always thirsting for another conquest. But its constant desire is hermaphroditic, and not merely because it encompasses men and women in history. Geist wishes to be filled and attempts to take its physical surroundings within itself, aspiring to encompass its world. Moreover, it reflects on its own activity in a way as to pleasure and stimulate itself, finding a void within itself that motivates its movements and activities. This activity resembles female masturbation, where Geist must dip itself into its own space that it encounters externally and must enter internally. As Hegel emphasises the sense of activity and movement involved in self-reflection, one may think of the way that Joe, in one scene, frantically masturbates to discover some sort of self-originating pleasure. However, the masturbation leaves her wanting a physical union with the external. Such a parallel opens up both the transgressive potential of Hegel's account of Geist in Phenomenology, and highlights 
the metaphysical side of Joe's quest.

The dimension of loss encountered by the physical and the physiological was significant to Hegel, for the body was part of the mind and not the other way around. Hegel in his preface observes that humanity has found it hard to find meaning in the material world, instead focusing on the beyond (1977: 5). It took an effort to emphasise worldly experience. 'Now we seem to need just the opposite', Hegel claims, because 'sense is so fast rooted in earthly things' (1977: 5). Hegel poetically observes that Geist is:

So impoverished that, like a wanderer in the desert craving for a mere mouthful of water, it seems to crave for its refreshment only the bare feeling of the divine in general. By the little which now satisfies Geist, we can measure the extent of its loss (1977: 5).

Joe is aware that something has been lost. Hegel is lamenting in the preface that Science no longer looks toward the spiritual, that it has become impoverished. There is an extent to which this tendency seems present in Seligman. Seligman is a romantic when it comes to nature but especially human nature. 'Seligman' is Yiddish for happy man. Moreover, the name may also be a reference to the psychologist and self-help author Martin Seligman. Yet, Seligman lives a life of unrecognised despair, hidden in his apartment and his wall of books, and routine, Seligman is emptied of higher pleasure. Joe recognises the emptiness of his humanism. When Seligman attempts to depict her in a positive light, she replies that his sympathetic explanations are 'frighteningly close to the clichés of our times' (2013: vol II). In another scene, Joe refuses the term 'sex addict', and rejects the purported infantilisation of understanding her urges as part of just an addiction (2013: vol II). She states that she loves her lust and that it is not a form of weakness. Nevertheless, Joe still distrusts Seligman's account of her actions that removes sin from her deeds.

Joe, in fact, is irked throughout by the way that Seligman and society fail to recognise and be delayed by the negative, the destructive core that pushes her on. Hegel locates the negative around death and destruction. In one of Hegel's more celebrated passages, he states:

The life of Geist is not the life that shrinks from death and keeps itself untouched by devastation, but rather the life that endures it and maintains itself in it. It wins its truth only when, in utter dismemberment, it finds itself. It is this power, not as something positive, which closes its eyes to the negative, as when we say of something that it is nothing or false, and then having done with it, turn away and pass onto something else; on the contrary the Spirit is this power only by looking the negative in the face, and tarrying with it. This tarrying with the negative is the magical power that converts it into being (1977: 19).

In other words, spiritual and psychical advancement - progress, only comes from a preparedness to tarry, and to reflect on suffering. Only through confronting existential questions that threaten our existence can we find any true affirmation. Joe is frustrated by those who do not share her probing, by those who close their eyes to the negative.

Seligman claims that Joe is not sinful and cursed. Joe, on the other hand willingly inflicts pain on herself, both physical and psychical in her quest. She faces up to the void that separates her from the rest of humanity. She rejects any positive thinking or 
any simple support mechanisms. Rather, she wants to live up to the 'power' of 'the negative'. She 'wants to look the negative in the face' and to be delayed by it, reflecting on it. As with Hegel's Geist, Joe inflicts spiritual and physical torture upon herself in an attempt to find herself in 'utter dismemberment'. This sense of being prepared to look harshly upon oneself and the world can be discerned in a scene in the 2014 Director's release where Joe describes an abortion that she performed on herself (vol II). She explains that because she was not under anaesthetic, her foetus would have felt pain. Seligman cannot stand to hear about the procedure of abortion despite being vehemently pro-choice. He even ventures that the general public should not know about the details. Joe points out that he is being hypocritical, given his self-professed humanism and his view that people should be aware of how the animals they consume are treated. He accuses her of sounding like she is 'pro-life and from Texas'. However, it is he who cannot acknowledge the various traumas that women often face. He notes the need for abortion and the very real cases of incest, rape and starving children and calls her position privileged. Yet Joe's abortion was self-performed. His logic sounds almost pro-life, claiming that her abortion was 'a luxury problem'. He makes the accusation against Joe even though she is pro-choice. She can live up to the moral ambiguity, and the details. The issue here is not the justification of abortion but the real sense of shame that may come with an abortion and the denial of a woman's experience. Seligman, despite his professed belief in human nature, cannot stomach that which goes against his idealistic conception of the world. He cannot stomach the various forms of negativity women go through. As Joe observes, 'I can see that it is all very convenient for men to leave all that abortion stuff to women. That way they don't have to deal with all the guilt, all the small stuff'.

After telling her story, which concludes with her attempting to kill Jerôme, Seligman reassures her that she has done nothing wrong. He explains to Joe that the reason the gun did not fire was because she did not rack the pistol. Seligman deduces that Joe never really intended to kill Jerôme. She therefore is not really a bad human being. While Joe is not altogether convinced by the modern pop psychology Seligman appropriates, Joe is still grateful for his friendship, and she no is no longer at war with herself. She says that by being able to tell her story, she is at ease, 'At this moment, my addiction is very clear to me and I've come to a decision'. She reveals that she wishes to rid herself of her sexuality, this ease with herself is really a war with herself. Seligman asks, 'is that a life worth living?' Joe replies, 'that is the only way I can live it'. She will use all her 'strength and masculine aggression' in this pursuit. She then tells Seligman that he is her, 'new and perhaps first friend'. He leaves Joe so that she can go to sleep, but moments later creeps into Joe's room. He has no trousers on. $\mathrm{He}$ goes over to her, while she is asleep. She wakes up, and asks him what he is doing, and then grabs the gun. The screen goes black. He protests: 'But you, you've fucked thousands of men' (2013: vol II). We hear the gun go off and the sounds of her fleeing from the apartment.

Joe's successful attempt to avoid sex is an example of her ability to triumph over what she takes to be her predetermined identity as a nymphomaniac. Her attempt is to transcend her nature through agency and recognition of her dark, internal impulses. In 
so doing, she hopes to become a subject. Yet, what Joe aspires to overcome, her own dangerous impulses, has failed. Joe wanted not to be a murderer - murder being the ultimate sin for her. At the end, Joe is at once triumphant over her own nature and defeated by it. As Slavoj Žižek points out, one way of interpreting Hegel is to argue that the ideational revelations and resolutions of antagonisms leave the bodily and physical reality in tact (2011). In which case, the constant flux of spiritual life continues. While consciousness seems to develop and resolves its contradictions, the processes of continual destruction and division go on, ceaselessly.

Georges Bataille references Hegel's insistence that death should be internalised within Geist and should become a part of its movement in his preface to Madame Edwarda (1941). What Bataille is gesturing toward, in this work, is the idea that the erotic is not merely funny or pathetic, but also, in some Hegelian sense, tragic and the subject of profound pathos. For Bataille, sex is linked to death and coming to terms with the horror of sex is like coming to terms with Hegel's notion of negative. Sex, so Bataille argues, opens up 'a vista of anguish' and a 'certain lacerating consciousness of distress' ([1941]2015: 124). Bataille explains that this sense of distress is the awareness of death. This awareness assumes the place of Hegel's tarrying with the negative. Sex, is it suggested by Bataille, is where we tarry with the negative, where the sense of sexual excess so challenges norms of reality as to appear closer to death. This sense of breaking barriers is not mere libertinage as it acknowledges the barriers in the first place. This acknowledgement is why, in a subversive way, Joe resembles Bataille's twisted Hegelianism, Hegel claiming that the Spirit progresses by acknowledging death and the negative as part of its being. Bataille's metaphysics in Madame Edwarda concerns the male protagonist, Pierre Angélique lusting after a prostitute who claims to be God, Madame Edwarda. Angélique concludes that she is indeed God or rather that her vagina is a void that is divine. This reference to a divine vagina is an allusion to Hegel's claim that God was an animating void (1977: 21). There is almost a parallel again with Nymphomaniac when Joe says, 'fill all my holes'. Her sentiment reflects that her quest emerges from the problematic and lamentably non-feminist idea that her body contains voids and lacks. However, these voids are what drive her and what strengthens her agency. As Hegel observed, 'the moving principle', namely a force that animates life and self-hood is the negative (1971:22). Indeed, as Hegel further states, the negative is the self, for the self is always defined by its opposition, that which it is not. Therefore, the self consists of its own separation from the world, and the self is always in this sense beyond definite location as its presence is always in the process of being defined. Hence, why Joe defines herself by her actions and against her actions. This view of selfhood helps us to understand why the way that Joe conceives of herself varies throughout the film. For instance, at one point, she claims that her only sin is to want more, then she claims that she is rotten to the very kernel of her being, then that she is proud of her sinfulness and finally that she must overcome herself. Her being is always transitional and this transitional quality makes her a dynamic figure, unlike Seligman.

To be defined by the negative implies that one is always what one is not. Since one must define oneself by opposition and difference, one internalises that difference into one's identity, meaning that the two, in some sense are united. Joe defines herself 
against what she calls 'society's morality police whose duty it is to erase my obscenity from the surface of the earth' (2013: vol II). Yet, she defines herself by moral strictures and codes which allow her to conceive of herself as a fallen, sinful human. Her sexual explorations encompass all judgements as she attempts to find truth through experiences of pain and pleasure. As Hegel observes, 'nothing is known that is not in experience, or, as it is also expressed, that is not felt to be true' (1978: 487). Since Geist must know itself through its opposites, truth and error are inseparable, Hegel arguing that 'truth is not a minted coin that can be given and pocketed ready-made' (1978: 22). Joe's story and Nymphomaniac involves a trial-and-error-approach to Joe's identity, where she can never quite locate herself or identity despite the various categorisations that Seligman attempts to impose upon her.

This sense of the undefined generates a feeling of abjection about both Joe and Hegel's Geist in Julia Kristeva's sense of the abject. In her work, Powers of Horror: An Essay on Abjection (1982), Kristeva analyses the abject as being between neither subject nor object, but having traces of both. According to Kristeva, the abject is that which is repulsive, not merely because it is intrinsically repellent but because it challenges our frames, and categories, which in turn suggests limits upon our agency. That which is abject does not fit easily into our framings of the world: vomit, excrement, blood and semen, are all related to people, to agents, and thus not merely things or objects. Yet, they are obviously not the people or the subjects themselves. This notion of abjection allows one to situate both Geist and Joe, for in the Spirit's movement toward being an all-knowing subject, the spirit undergoes abject experiences, unable to achieve what Hegel calls absolute knowing. This inability renders the subject estranged from itself, feeling unable to ever be content by its own categories, a sense that likewise pervades Joe. Yet, this sense, as Kristeva points out, is appealing as the abject is always cast off from the human and therefore seems to offer a beyond to the subject, something more. It is repellent and attractive, enticing Geist and Joe further and further.

Geist, claims Hegel, has a Dionysian quality to its phenomenological encounters, consuming all experiences (1977: 27). Consumption is important to Hegel's conception of Geist. Geist almost resembles the spirit of capitalism, restless, dissatisfied, always craving more which raises the question of whether Geist predicts the rampant consumption associated with late capitalism's neo-liberal manifestation. If Joe is an embodiment of Geist is she just another pleasure-seeking consumer? While Joe's sexual experiences have a metaphysical or religious aspect to them, this quality itself does not negate the comparison to consumerism. Žižek observes in his book First as Tragedy, then as Farce (2009), that 'we primarily buy commodities neither on account of their utility nor as status symbols; we buy them to get the experience provided by them, we consume them in order to render our lives pleasurable and meaningful' (52). Indeed, consumerism is not driven, so Žižek claims, by the id but by the superego which makes us feel guilty if we are not having fun and leads us to embrace a decaffeinated existence. According to Žižek, our superego torments us if we are not having a good time to the extent that we must be able to buy a Starbucks coffee and know that a percentage of the proceeds go to charity, thereby annulling any sense that we are being selfish consumers, affirming the goodness of pleasure and indulgence (2009: 53-54). However, this 
superego-driven pleasure negates the negative which in turn negates Geist's movement. In a scene where Joe goes to sex therapy she speaks to her therapist who informs her that unlike other addictions, sex is a necessary part of life and should not be eliminated altogether (2014: vol II). Instead, it should be rendered safe and controllable, something to be had now and then. Joe recognises this as a type of hypocritical moralism with implied guilt. She opposes the idea, arguing that either the sordid qualities of sex should be embraced or it should be abandoned altogether. The difference then between Joe and a capitalist consumer is that Joe examines her own actions, she reflects on her urges and is ready to think the worst of herself, unlike in capitalist societies where, so Žižek claims, the superego instructs us that we must always be happy with ourselves, forgive ourselves. Indeed, Joe rejects even the claims of her emancipatory potential. In so doing, she becomes truly radical and subversive and doomed. Joe thereby becomes part of Geist's progress in a time when the Geist has become dispirited, and lacks the generative ability to progress through its dismembered and scattered form.

Joe's very quest through abjection for that which is beyond societal norms is forever destined to lead to frustration, exhaustion and despair, as well as moments of strength and recovery. Her desires are based on an urge to be united with the world, and an urge to go beyond the world, beyond custom. As she tells Seligman, "perhaps the only difference between me and other people is that I've always demanded more from the sunset. More spectacular colours as the sun hit the horizon' (2013: vol I). To what extent Joe is a free and rational subject is difficult to know. Joe seems to have broken free in the very moment that confirms her own continued imprisonment. As with Hegel's Geist, her identity is permanently purgatorial, an ongoing blend of failure and triumph. She inhabits a half-way space, where her spirit or Geist aspires to salvation through hell and forever finds itself returning to purgatory. In this way von Trier's film, one might think, would be based around the ecstatic and the orgasmic, but it focuses as much on Joe's failures. The film has, to borrow Yukio Mishima's description of Madame Edwarda, an 'erotic intellectualism' - a descriptor that applies to Joe's self-analysis (2015: 3). Her encounters with Jerôme illustrate her inability to find a spiritual and physical consummation. Despite her ongoing psychical development, her body remains battered and bruised and her desires intact. She reflexively experiences that world until the close of the film, a seeming consummation where she commits the last transgression of murder. And yet, she then goes on, leaving Seligman's apartment. The film leaves open whether she is defeated or triumphant but in the spirit of Hegel (if one excuses the bad pun), I think she's both.

\section{Conclusion}

Nymphomaniac is a film that objectifies the fictional heroine's sexual experience through its storytelling. In many ways, von Trier's film appears to be an exercise in marketing. In order to enter the film's website, one had to scroll up and pass through parentheses that resembled a minimalist vagina-void. The infamous trailer includes images of vaginas, oral sex, allusions to sado-masochism, and sexual moistness dripping down Joe's leg. The cultural theorist, Steven Shaviro observed on Twitter that he was not looking forward to Nymphomaniac as there was, 'nothing more 
conservative/conformist today than the attempt to shock \& to reproach prudishness' (2013). Yet, as Shaviro also commented/tweeted, 'the sex is boring, but the emotionally embarrassing \& excruciating parts that go on and on are great' (2014). Indeed, I argue the film is not about the sex, but about Joe's analysis of sex. In a Hegelian way, the sex is manifested as simultaneous and yet mediated and reflected upon, becoming a part of Joe and Joe's search for agency and subjectivity. The film is more complicated than the hype that surrounds it. Kristal Lowe argues that the Twilight saga is able to both convey reactionary and emancipatory explorations of gender (in the final article in this Special Issue). A similar dynamic in Nymphomaniac occurs with Joe remaining subversive despite the challenges she raises to feminism. Unlike the other characters in Nymphomaniac, it is only Joe who appreciates her own agency. She does this by making herself into an object, but an object of subjective power, and not an object in a masculine, instrumentalised framework. For Hegel the subject renders itself an object of its contemplation - the self becoming a tool for transcendence. According to Hegel, we become ourselves by making ourselves other and recognising that all that defines us is the negative which is ' $\mathrm{I}$ ', namely the difference within ourselves and between ourselves and others. Joe's position seems to be that the sexual subject must objectify herself. She embarks on an experience of learning and mapping herself, where she learns how she is objectified and learns to resist the objectification through making herself her own object - which Hegel realised was the end result of Immanuel Kant's mapping of reason. The subject is one who autonomously evaluates him- or herself as an agent, who is able to make moral judgments against themselves and grasp some degree of self-knowledge through relentless self-interrogation and self-negation. This process of self-negation and by extension, the transcending of the self, has a spiritual dimension in Hegel and von Trier.

There has long been a tradition of suggesting that a woman's suffering can be a source of spiritual transcendence - one need only think of the image of Mary, Mother of God. There has even been a tradition of suggesting that a woman's spiritual and sexual ekstasis is a point of jouissance that merges pain with pleasure in works such as Bernini's sculpture The Ecstasy of Saint Teresa (1647-1652) or Bataille's story, Madame Edwarda. However, what Nymphomaniac reveals is that the personal is political, but also that it is potentially theological and forever paradoxical, suggesting that trauma, disappointment and generative instincts toward the emancipatory are often enmeshed. This approach to storytelling is, as discussed here, not always without controversy but such narratives can challenge mainstream conceptions of what "good" storytelling is and so can increase the number of opportunities for us to create and consume stories. Such stories are complicated and require a paradoxical literary and philosophical framing to appreciate how they lead the responders' consciousness, and indeed, explore the protagonist's layered experience.

\section{Endnotes}

1. The complete lyrics can be heard during the credits, these have been translated here using Google Translate, which has its limitations, and checked against the various translations of the original 2009 version of the song. 
2. Modified version for the film: a different version was originally released in 2009 . The song can be heard in the film or at https://www.youtube.com/watch?v=jzARL6LmodQ Accessed 24 November 2015

\section{Works cited}

Bach, JS 1732 Ich ruf zu dir, Herr Jesu Christ, BWV 639 - 'I call to you, Jesus Christ' Church Cantata Bataille, G [1941]2015 'Madame Edwarda’ JJ Pauvert (trans) My Mother, Madame Edwarda, The Dead Man London: Penguin Classic (ebook)

Bernini, GL 1647-1652 'The Ecstasy of Saint Teresa' [sculpture] Rome: Santa Maria della Vittoria Brooks, X 2009 'Antichrist: A Work of Genius or the Sickest Film in the History of Cinema?' The Guardian http://www.theguardian.com/film/2009/jul/16/antichrist-lars-von-trier-feminism Accessed 24 November 2015

Faber, A 2003 'Redeeming Sexual Violence? A Feminist Reading of Breaking the Waves' Literature \& Theology 17(1): 59-75

Findlay, JN 1979 'Foreword' Hegel's Phenomenology of Spirit Oxford: Oxford UP, v-xxx

Foucault, M 1978 R Hurley (trans) The History of Sexuality I New York: Penguin

Franks, R 2016 ‘A Woman's Place: Constructing Women Within True Crime Narratives' TEXT: Journal of Writers and Writing Courses Special Issue 34

Galt, R 2015 'The Suffering Spectator?: Perversion and Complicity in Antichrist and Nymphomaniac' Theory \& Event 18(2)

https://muse.jhu.edu/login?auth=0\&type=summary\&url=/journals/theory_and_event/v018/18.2.galt.ht $\mathrm{ml}$ Accessed 9 September 2015

Hegel, GWF 1977 AV Miller (trans) Hegel's Phenomenology of Spirit Oxford: Oxford UP

Keefer, K and T Linafelt 1999 'The End of Desire: Theologies of Eros in The Song of Songs and Breaking the Waves' SB Plate and D Jasper (eds) Imag(in)ing Otherness: Filmic Visions of Living Together Atlanta: Scholars P (ebook), 49-59

Kristeva, J 1982 LS Roudiez (trans) Powers of Horror: An Essay on Abjection New York: Columbia UP

Lowe, K 2016 'Time and the Making and Re-making of the Feminine Gendered Subject in Stephanie Meyer's Twilight saga' TEXT: Journal of Writers and Writing Courses Special Issue 34

Mishima, Y 2015 'George Bataille and Divinus Deus' K Hollings and A Hada (trans) My Mother, Madame Edwarda, The Dead Man London: Penguin Classic (ebook)

Mozart, WA 1791-1792 The Requiem Mass in D Minor

Pahl, K 2011 'The Way of Despair' S Žižek, C Crockett and C Davis (eds) Hegel and the Infinite: Religion, Politics, and Dialectic New York: Columbia UP (ebook)

Pinkard, T 2013 German Philosophy 1760-1860: The Legacy of Idealism Cambridge: Cambridge UP Rammstein 2013 Führe Mich ${ }^{2}$

Redding, P 2010 ‘Georg Wilhelm Friedrich Hegel’ EN Zalta (ed) The Stanford Encyclopedia of Philosophy, Spring 2014 http://plato.stanford.edu/archives/spr2014/entries/hegel Accessed 14 March 2015

Shaviro, S 2013 7.27am 18 December Tweet: @Shaviro https://twitter.com/shaviro Accessed 9 September 2015

Shaviro, S 2014 10:23am 9 March Tweet: @Shaviro https://twitter.com/shaviro Accessed 9 September 2015 
Vesth, L (producer) and L von Trier (director) 2013 Nymphomaniac: I and II Denmark: Zentropa Entertainments

Vesth, L (producer) and L von Trier (director) 2014 Nymphomaniac: Extended Director's Cut: II Denmark: Zentropa Entertainments

Žižek, S 2009 First as Tragedy, Then as Farce London: Verso

Žižek, S 2011 'Hegel and Shitting: The Idea's Constipation' S Žižek, C Crockett and C Davis (eds) Hegel and the Infinite: Religion, Politics, and Dialectic New York: Columbia UP (ebook) 